\title{
Camptothecin Analogue TLC388
}

National Cancer Institute

\section{Source}

National Cancer Institute. Camptothecin Analogue TLC388. NCI Thesaurus. Code C80047.

A synthetic analogue of camptothecin with potential antineoplastic and radio-sensitizing activities. Camptothecin analogue TLC388 selectively stabilizes topoisomerase I-DNA covalent complexes during S-phase, thereby inhibiting religation of topoisomerase Imediated sing le-strand DNA breaks and producing potentially lethal double-strand DNA breaks when encountered by the DNA replication machinery. Topoisomerase I relaxes negative super-coiled DNA during replication and transcription. This agent has been chemically modified to enhance the potency and stability of camptothecin. 